\title{
Knowledge of marine fish trematodes of Atlantic and Eastern Pacific Oceans
}

\author{
Rodney A. Bray • Pablo E. Diaz • \\ Thomas H. Cribb
}

Received: 16 November 2015/ Accepted: 7 January 2016

(C) The Author(s) 2016. This article is published with open access at Springerlink.com

\begin{abstract}
A brief summary of the early history of the study of Atlantic Ocean marine fish digeneans is followed by a discussion of the occurrence and distribution of these worms in the Atlantic Ocean and adjacent Eastern Pacific Ocean, using the Provinces of the 'Marine Ecoregions' delimited by Spalding et al. (Bioscience 57:573-583, 2007). The discussion is based on a database of 9,880 records of 1,274 species in 430 genera and 45 families. 8,633 of these records are from the Atlantic Ocean, including 1,125 species in 384 genera and 45 families. About 1,000 species are endemic to the Atlantic Ocean Basin. The most species-rich families in the Atlantic Ocean are the Opecoelidae Ozaki, 1925, Hemiuridae Looss, 1899 and Bucephalidae Poche, 1907, and the most widespread the Opecoelidae, Hemiuridae, Acanthocolpidae Lühe, 1906, Lepocreadiidae Odhner, 1905 and Lecithasteridae Odhner, 1905. A total of 109 species are shared by the Atlantic Ocean and the Eastern Pacific, made up of cosmopolitan, circum-boreal,
\end{abstract}

Special Issue on Biodiversity of Trematodes of Fishes, Guest Edited by Thomas H. Cribb.

R. A. Bray $(\bowtie)$

Department of Life Sciences, Natural History Museum,

Cromwell Road, London SW7 5BD, UK

e-mail: rab@nhm.ac.uk

P. E. Diaz - T. H. Cribb

School of Biological Sciences, The University of

Queensland, St Lucia, QLD 4072, Australia
trans-Panama Isthmus and Magellanic species. The lack of genetic evaluation of identifications is emphasised and the scope for much more work is stressed.

\section{Introduction}

The study of the marine trematode fauna of the world can be said to have started in the Atlantic Ocean basin, although the earliest recognisable post-Linnaean name to be coined for a marine digenean is probably Fasciola ventricosa Pallas 1774, now recognised as Hirudinella ventricosa (Pallas, 1774) Baird, 1853, a large stomach parasite of large scombrid fishes originally reported from Ambon Island, Indonesia but now reported worldwide (Pallas, 1774; Gibson, 1976). Other early descriptions which are still recognised include Fasciola varicus Müller, 1784, now known as the widespread and common species Derogenes varicus (Müller, 1784) Looss, 1901, originally reported from Danish waters (Müller, 1784). Carl Rudolphi in the early 19th Century made important early contributions, describing many worms from the Mediterranean Sea which are still recognised. Pérez-del-Olmo et al. (2016) considers these and the contributions of other workers in the Mediterranean. In the open Atlantic Ocean, Félix Dujardin (1845) described several species, such as those now recognised as Cainocreadium labracis (Dujardin, 1845) Nicoll, 1909, Macvicaria soleae (Dujardin, 1845) Gibson \& Bray, 1982 and Podocotyle angulata Dujardin, 1845 off the 
Brittany coast, France. Other early workers in the north-eastern Atlantic include Thomas Spencer Cobbold (1858) who described the worm now recognised as Lepidapedon rachion (Cobbold, 1858) Stafford, 1904, presumably from a haddock apparently examined at Edinburgh, Scotland. Peter Olsson described many worms from the Scandinavian coasts (e.g. Olsson 1868) including many still recognised including Steringophorus furciger (Olsson, 1868) Odhner, 1905, Zoogonoides viviparus (Olsson, 1868) Odhner, 1902, Zoogonus rubellus (Olsson, 1868) Odhner, 1902 and Fellodistomum fellis (Olsson, 1868) Nicoll, 1909. Édouard van Beneden illustrated some worms from the Belgian coast (e.g. van Beneden, 1871) including those now recognised as Steringotrema pagelli (van Beneden, 1871) Odhner, 1911 and Otodistomum cestoides (van Beneden, 1871) Stafford, 1904.

Little was done in the Western or Southern Atlantic during the 19th Century. Joseph Leidy (1891) described a cercaria, Distomum lasium, from off New Jersey, USA, which is now recognised as Zoogonus lasius (Leidy, 1891) Stunkard, 1940. Edwin Linton started describing digeneans from various localities off the North American coast in the late 19th Century (e.g. Linton, 1889) and continued into the 20th Century with his most important work on the Tortugas of Florida (Linton, 1910) and a (posthumous) publication in 1940. Many of his species are still recognised including Macvicaria crassigula (Linton, 1910) Bartoli, Bray \& Gibson, 1989, Opechona pyriforme (Linton, 1900) Bray \& Gibson, 1990, Opecoeloides vitellosus (Linton, 1899) von Wicklen, 1946, Prosorhynchoides arcuatus (Linton, 1900) Love \& Moser, 1983 and Lintonium vibex (Linton, 1900) Stunkard \& Nigrelli, 1930.

Modern generic concepts began to be developed in the early 20th Century by Max Lühe and Arthur Looss in the Mediterranean and Teodor Odhner in the Atlantic. An important early work by the latter on Arctic worms (Odhner, 1905), was one of many by this author, many of whose species are still recognised in the genera in which he placed them, such as Lecithaster confusus Odhner, 1905, Hemiurus levinseni Odhner, 1905, Aporocotyle simplex Odhner, 1900, Prosorhynchus aculeatus Odhner, 1905, Hemiurus communis Odhner, 1905, Proctophantastes abyssorum Odhner, 1911 and many more. Other north-eastern Atlantic workers of the early 20th Century are the British workers William Nicoll and Marie Lebour, whose contributions include the recognised species Fellodistomum agnotum Nicoll,
1909, Peracreadium idoneum (Nicoll, 1909) Gibson \& Bray, 1982, Diphterostomum vividum (Nicoll, 1912) Bray \& Gibson, 1986, Lepidapedon elongatum (Lebour, 1908) Nicoll, 1910 and Steringotrema ovacutum (Lebour, 1908) Yamaguti, 1953.

In the early years of the 20th Century the northwestern Atlantic digeneans were studied notably by Joseph Stafford and Edwin Linton. Stafford (1904) described, but did not illustrate, worms from off the eastern Canadian coast. The fact that several are still recognised, e.g. Homalometron pallidum Stafford, 1904, Neophasis pusilla Stafford, 1904, Stenakron vetustum Stafford, 1904 and Steganoderma formosum Stafford, 1904, is due to the restudy of Stafford's material by Max Miller (Miller, 1941).

No summary of the early work in the Atlantic Ocean would be complete without a mention of the contribution of Harold Manter. Starting in 1925 (Manter, 1925), he described many of the worms now recognised. There is no room to list them all, but they include Dermadena lactophrysi Manter, 1945, Genolinea laticauda Manter, 1925, Gonocerca phycidis Manter, 1925, Multitestis blennii Manter, 1931, Megasolena hysterospina (Manter, 1931) Overstreet, 1969, Genolopa elongata Manter, 1931, Genolopa minuta Manter, 1931, Proctotrema lintoni Manter, 1931 and Prodistomum menidiae (Manter, 1947) Bray \& Gibson, 1990.

The study of the marine digenean fauna in the South Atlantic developed later. The first report in our database from the southwestern Atlantic is that of Monorcheides popovicii Szidat, 1950 from off Tierra del Fuego (Szidat, 1950) and those from the southeastern Atlantic are six monorchiids from off the coast of Ghana (Thomas, 1959).

Two other workers should be mentioned, due to their major contribution to the knowledge of digenean lifecycles in the Atlantic fauna. The first is Horace Stunkard who elucidated the life-cycle of Zoogonoides laevis Linton, 1940, Proctoeces maculatus (Looss, 1901) Odhner, 1911, Stephanostomum dentatum (Linton, 1900) Manter, 1940, Opechona pyriforme, Lintonium vibex, Lepocreadium areolatum (Linton, 1900) Stunkard, 1969, Tubulovesicula pinguis (Linton, 1940) Manter, 1947, Lasiotocus minutus (Manter, 1931) Thomas, 1959, Neopechona cablei Stunkard, 1980 and others (e.g. Stunkard \& Uzmann, 1959). The other is Marianne Køie whose astonishing ability to coax digeneans into revealing their secrets allowed her to elucidate many life-cycles including those of Opechona 
bacillaris (Molin, 1859) Dollfus, 1927, Zoogonoides viviparus, Stephanostomum caducum (Looss 1901) Manter, 1934, Monascus filiformis (Rudolphi, 1819) Looss, 1907, Steringophorus furciger (Olsson, 1868) Odhner, 1905, Derogenes varicus, Steringotrema pagelli, Fellodistomum fellis, Podocotyle reflexa (Creplin, 1825) Odhner, 1905, Aporocotyle simplex, Lepidapedon elongatum, Lecithaster gibbosus (Rudolphi, 1802) Lühe, 1901, Lecithochirium rufoviride (Rudolphi, 1819) Lühe, 1901, Hemiurus luehei Odhner, 1905, Lecithocladium excisum (Rudolphi, 1819) Lühe, 1901, Magnibursatus caudofilamentosa (Reimer, 1971) Gibson \& Køie, 1991, Brachyphallus crenatus (Rudolphi, 1802) Odhner, 1905 and Hemiurus communis Odhner, 1905 (e.g. Køie 1975, 1995).

\section{Database and methods}

A database in the form of an Excel spreadsheet has been developed for the marine fish trematodes of the Atlantic Ocean. This is based predominantly on the work of one of us (THC) and his students, who have used the literature to write over 25,000 lines. The Atlantic and Eastern Pacific Ocean records from this database have been extracted and some further records have been added (by RAB and PED). The locality records have been coded according to Provinces of the 'Marine Ecoregions' delimited by Spalding et al. (2007) (see Table 1, Fig. 1A). These are 'Large areas defined by the presence of distinct biotas that have at least some cohesion over evolutionary time frames' (Spalding et al., 2007). Eastern Pacific Ocean Provinces are included for comparative purposes. The 'Magellanic Province' spans both Oceans as it includes the North Patagonian Gulfs, the Patagonian Shelf, the Falklands, the Channels and Fjords of Southern Chile and Chiloense. Overall data included in the survey include this Province in the discussion of the Atlantic fauna. The database suffers from the problems inherent in this type of enterprise, such as errors in entry, duplicates, omissions, typos (both in original reports and data entry), wrong attributions and unrecognised synonymies. Another problem is the lack of precision in the locality descriptions in many papers. These records have been omitted. Also omitted from the main analysis have been records of parasites and/or fishes which have not been identified to species. It has not been possible to consider the validity and synonymies of all the species,
Table 1 Atlantic and Eastern Pacific Provinces of the 'Marine Ecoregions' delimited by Spalding et al. (2007)

\begin{tabular}{ll}
\hline No. & Description \\
\hline 1 & Arctic \\
2 & Northern European Seas \\
3 & Lusitanian \\
4 & Mediterranean Sea \\
5 & Cold Temperate Northwest Atlantic \\
6 & Warm Temperate Northwest Atlantic \\
7 & Black Sea \\
10 & Cold Temperate Northeast Pacific \\
11 & Warm Temperate Northeast Pacific \\
12 & Tropical Northwest Atlantic \\
13 & North Brazil Shelf \\
14 & Tropical Southwestern Atlantic \\
15 & St Helena and Ascension Islands \\
16 & West African Transition \\
17 & Gulf of Guinea \\
43 & Tropical East Pacific \\
44 & Galapagos \\
45 & Warm Temperate Eastern Pacific \\
47 & Warm Temperate Southwestern Atlantic \\
48 & Magellanic \\
49 & Tristan Gough \\
50 & Benguela \\
\hline &
\end{tabular}

but in general the names follow that used in the World Register of Marine Species (WoRMS Editorial Board, 2015), compiled mainly by Dr David Gibson, and the series of 'Keys to the Trematoda' (Gibson et al., 2002; Jones et al., 2005; Bray et al., 2008).

\section{Results}

Considering the number of records accumulated, it might be considered that we know a good proportion of the fauna, but the effort in different parts of the Ocean has certainly not been even.

The following data relating to the 17 regions of the Atlantic Ocean have been collated, along with the five Eastern Pacific regions: the number of species, genera and families in each region, the number of lines in the database per species, genus and family. These latter three parameters give an estimate of the effort in each region (Table 2). The number of lines in the database for each region is displayed on the Map (Fig. 1B). 
Table 2 Number of lines in the database, species, genera, families and data on effort for the 'Spalding et al.' regions of the Atlantic and eastern Pacific Oceans

\begin{tabular}{|c|c|c|c|c|c|c|c|c|}
\hline & Region & Lines & Species & Genera & Families & $\begin{array}{l}\text { Lines } \\
\text { per species }\end{array}$ & $\begin{array}{l}\text { Lines } \\
\text { per genus }\end{array}$ & $\begin{array}{l}\text { Lines } \\
\text { per family }\end{array}$ \\
\hline \multirow[t]{17}{*}{ Atlantic } & 1 & 476 & 66 & 46 & 16 & 7.2 & 10.3 & 29.8 \\
\hline & 2 & 1,302 & 169 & 101 & 25 & 7.7 & 12.9 & 52.1 \\
\hline & 3 & 350 & 126 & 86 & 26 & 2.8 & 4.1 & 13.5 \\
\hline & 4 & 2,138 & 330 & 159 & 30 & 6.5 & 13.4 & 71.3 \\
\hline & 5 & 884 & 160 & 93 & 26 & 5.5 & 9.5 & 34.0 \\
\hline & 6 & 491 & 163 & 79 & 22 & 3.0 & 6.2 & 22.3 \\
\hline & 7 & 292 & 85 & 58 & 17 & 3.4 & 5.0 & 17.2 \\
\hline & 12 & 2,107 & 422 & 195 & 36 & 5.0 & 10.8 & 58.5 \\
\hline & 13 & 0 & 0 & 0 & 0 & 0 & 0 & 0 \\
\hline & 14 & 6 & 6 & 6 & 5 & 1.0 & 1.0 & 1.2 \\
\hline & 15 & 1 & 1 & 1 & 1 & 1.0 & 1.0 & 1.0 \\
\hline & 16 & 86 & 42 & 39 & 18 & 2.0 & 2.2 & 4.8 \\
\hline & 17 & 117 & 56 & 45 & 17 & 2.1 & 2.6 & 6.9 \\
\hline & 47 & 320 & 134 & 88 & 25 & 2.4 & 3.6 & 12.8 \\
\hline & 48 & 60 & 22 & 18 & 10 & 2.7 & 3.3 & 6.0 \\
\hline & 49 & 1 & 1 & 1 & 1 & 1.0 & 1.0 & 1.0 \\
\hline & 50 & 2 & 2 & 1 & 1 & 1.0 & 2.0 & 2.0 \\
\hline \multirow[t]{5}{*}{ Pacific } & 10 & 333 & 86 & 54 & 18 & 3.9 & 6.2 & 18.5 \\
\hline & 11 & 463 & 139 & 98 & 26 & 3.3 & 4.7 & 17.8 \\
\hline & 43 & 291 & 128 & 90 & 24 & 2.3 & 3.2 & 12.1 \\
\hline & 44 & 55 & 33 & 24 & 11 & 1.7 & 2.3 & 5.0 \\
\hline & 45 & 105 & 39 & 32 & 18 & 2.7 & 3.3 & 5.8 \\
\hline
\end{tabular}

As can be seen, the Tropical Northwest Atlantic (12) has the most described species, followed by the Mediterranean Sea (4). In terms of lines per taxon, the Northern European Seas Province (2) is the most studied region, but the Arctic (1), Mediterranean Sea (4) and possibly the Cold Temperate Northwest Atlantic (5) and the Tropical Northwest Atlantic (12), have very similar levels of effort. The effort in the southwestern Atlantic (13, 14, 47, 48) is considerably less and no records were recovered from the North Brazilian Shelf Province (13). The best known fauna from this region is Warm Temperate Southwestern Atlantic (47). The south-eastern Atlantic (16, $17,50)$ is the least studied continental coastal zone (with only two records recovered from the Benguela region -50). The two mid-Southern Atlantic Island provinces (15 and 49) have only one record each.

The database has in total 9,880 records of 1,274 species in 430 genera and 45 families, of which 8,633 are from the Atlantic Ocean, with 1,125 species in 384 genera and 45 families. About 1,000 species are endemic to the Atlantic Ocean basin, but Lessepsian migrants and other identifications of Indo-West Pacific species confuse the picture.

A major problem with interpretation of the database in this fashion is that it is reliant on accurate identifications. In addition, little effort has been made, hitherto, to explore the genetic validity of Atlantic species. Relatively recent works by, for example, Jousson (Jousson et al., 1999, 2000; Jousson, 2001), BlascoCosta (Blasco-Costa et al., 2009a, b, 2010), Antar (Antar et al., 2015) in the Mediterranean and Curran, Pulis and Andres (Andres et al., 2014; Curran \& Pulis, 2014; Pulis et al., 2014) in the Gulf of Mexico, are the exception. In the wider Atlantic the study of some deep-sea species of Lepidapedon Stafford, 1904 and other lepidapedids and fellodistomids (Lumb et al., 1993; Bray et al., 1994, 1999) has shown that cryptic species are common. New investigations should, wherever possible, include molecular evidence for the status of taxa. 


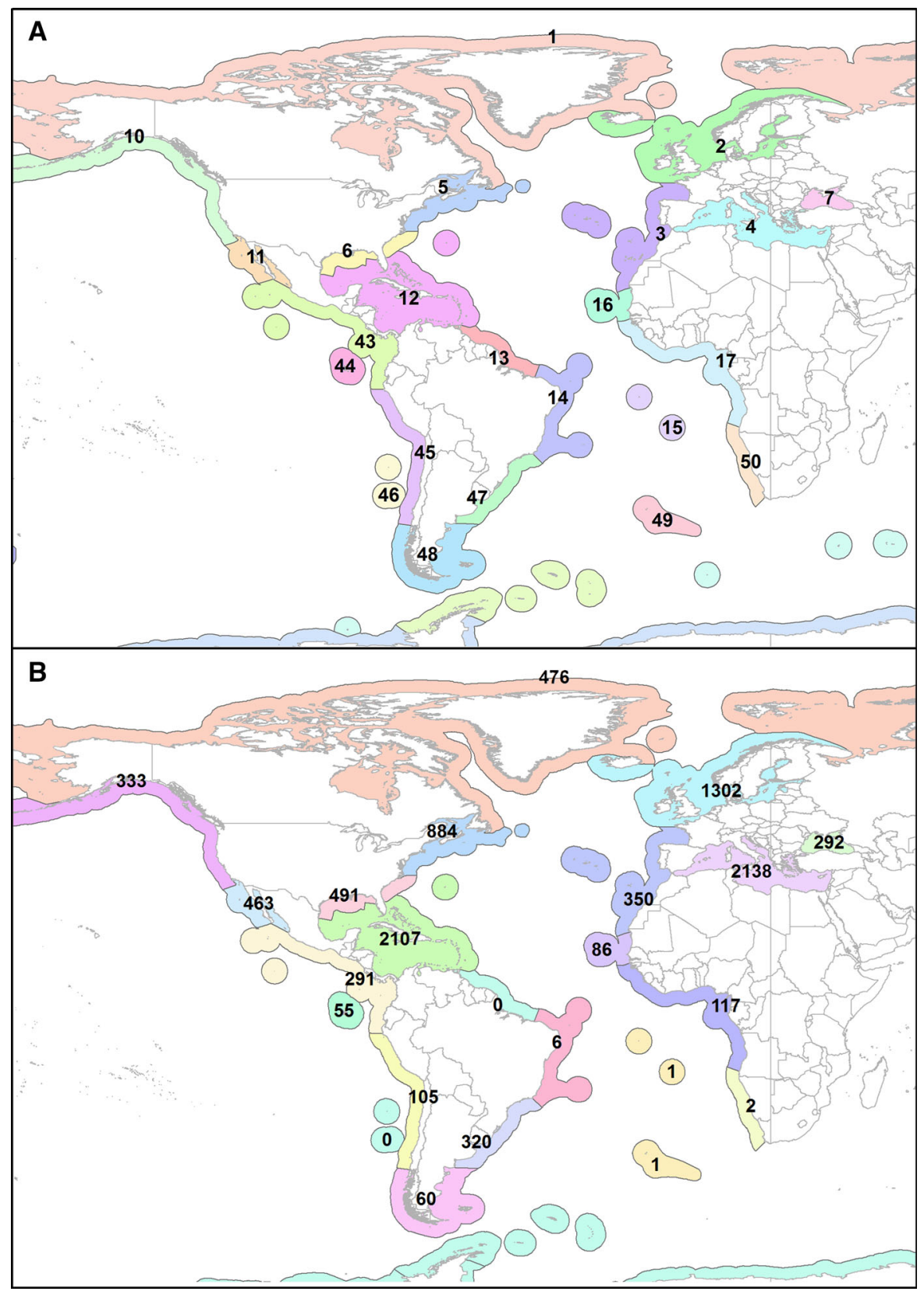

Fig. 1 A, Map of the Atlantic and Eastern Pacific Oceans, showing 'Spalding et al.' Region Numbers; B, Map of the Atlantic and Eastern Pacific Oceans, showing the number of records (lines in the database) of digeneans in each Region

Lack of precision in identification of parasites, i.e. those quote as 'sp.' or 'spp.', may be an indicator of the lack of taxonomic work in certain areas, where other specialists, e.g. ecologists, have been active. We have 66 such records from the Tropical Northwest Atlantic (Region 12) and 65 from the Mediterranean Sea (4) and the Warm Temperate Eastern Pacific (45). Considering the relatively few records of identified species in Region 45 (39\% records are of unidentified worms), it seems clear that workers in this region, particularly in Chile and Peru, have suffered from a distinct taxonomic deficiency. On the other hand, Regions 12 and 4 are the 
most thoroughly studied regions and the number of records of unidentified parasites is relatively low (about $3 \%$ in both regions).

\section{The status of digenean families in the Atlantic Ocean}

The number of genera and species found in the families in the Atlantic Ocean are listed in Table 3, the distribution of records of the families in the Atlantic Ocean are listed in Table 4, and the distribution of reports of the three most species-rich families are illustrated in Figures 2-4.

The most species-rich, and jointly the most widespread, family is the Opecoelidae Ozaki, 1925 (Fig. 2), which is found in 13 of the 17 Atlantic regions. Considering that four of the zones are more or less completely unstudied, this presumably means that they are found in all zones. The second most species-rich family, the Hemiuridae Looss, 1899 has a very similar distribution pattern (Fig. 3). The third most species-rich family, the Bucephalidae, is found in fewer zones (11) than three less species-rich families (Fig. 4, Table 3). It is notable that the number of genera in the Bucephalidae Poche, 1907 is relatively few, but molecular results indicate that most of the currently recognised genera are polyphyletic (Nolan et al., 2015). Apart from the four more or less unstudied regions mentioned above (13, 15, 49 and 50), records of bucephalids are missing from the Magellanic (48) and the Tropical Southwestern Atlantic (14) regions. These are also poorly studied regions, and it is likely that bucephalids are, in fact, found in all regions.

The Atlantic is depauperate in some families that are relatively common in the Indo-West Pacific Region: the Gyliauchenidae Fukui, 1929, Enenteridae Yamaguti, 1958, Opistholebetidae Fukui, 1929 and

Table 3 Numbers of genera and species in each family represented in the Atlantic Ocean

\begin{tabular}{|c|c|c|c|c|c|}
\hline Family & $\begin{array}{l}\text { No. of } \\
\text { genera }\end{array}$ & $\begin{array}{l}\text { No. of } \\
\text { species }\end{array}$ & Family & $\begin{array}{l}\text { No. of } \\
\text { genera }\end{array}$ & $\begin{array}{l}\text { No. of } \\
\text { species }\end{array}$ \\
\hline Opecoelidae Ozaki, 1925 & 50 & 160 & Azygiidae Lühe, 1909 & 2 & 7 \\
\hline Hemiuridae Looss, 1899 & 32 & 101 & Enenteridae Yamaguti, 1958 & 2 & 7 \\
\hline Bucephalidae Poche, 1907 & 11 & 92 & Pronocephalidae Looss, 1899 & 5 & 6 \\
\hline Didymozoidae Monticelli, 1888 & 29 & 74 & Syncoeliidae Looss, 1899 & 3 & 5 \\
\hline Acanthocolpidae Lühe, 1906 & 10 & 72 & Hirudinellidae Dollfus, 1932 & 4 & 4 \\
\hline Lepocreadiidae Odhner, 1905 & 25 & 69 & Gyliauchenidae Fukui, 1929 & 2 & 4 \\
\hline Monorchiidae Odhner, 1911 & 20 & 64 & Lissorchiidae Magath, 1917 & 2 & 4 \\
\hline Fellodistomidae Nicoll, 1909 & 24 & 53 & Diplangidae Yamaguti, 1971 & 1 & 4 \\
\hline Zoogonidae Odhner, 1902 & 19 & 40 & Cladorchiidae Fischoeder, 1901 & 2 & 3 \\
\hline Lecithasteridae Odhner, 1905 & 13 & 40 & Dictysarcidae Skrjabin \& Guschanskaja, 1955 & 2 & 3 \\
\hline Cryptogonimidae Ward, 1917 & 18 & 38 & Microphallidae Ward, 1901 & 2 & 3 \\
\hline Aporocotylidae Odhner, 1912 & 15 & 38 & Bivesiculidae Yamaguti, 1934 & 1 & 3 \\
\hline Haploporidae Nicoll, 1914 & 13 & 35 & Microscaphidiidae Looss, 1900 & 1 & 3 \\
\hline Derogenidae Nicoll, 1910 & 10 & 34 & Opistholebetidae Fukui, 1929 & 1 & 2 \\
\hline Lepidapedidae Yamaguti, 1958 & 8 & 31 & Bathycotylidae Dollfus, 1932 & 1 & 1 \\
\hline Apocreadiidae Skrjabin, 1942 & 10 & 29 & Botulisaccidae Yamaguti, 1971 & 1 & 1 \\
\hline Haplosplanchnidae Poche, 1926 & 4 & 22 & Brachycladiidae Odhner, 1905 & 1 & 1 \\
\hline Gorgoderidae Looss, 1899 & 6 & 19 & Deropristidae Cable \& Hunninen, 1942 & 1 & 1 \\
\hline Accacoeliidae Looss, 1899 & 8 & 15 & Echinostomatidae Looss, 1899 & 1 & 1 \\
\hline Sclerodistomidae Odhner, 1927 & 6 & 10 & Gorgocephalidae Manter, 1966 & 1 & 1 \\
\hline Faustulidae Poche, 1926 & 6 & 9 & Opisthorchiidae Looss, 1899 & 1 & 1 \\
\hline Aephnidiogenidae Yamaguti, 1934 & 4 & 7 & Ptychogonimidae Dollfus, 1937 & 1 & 1 \\
\hline Mesometridae Poche, 1926 & 4 & 7 & & & \\
\hline
\end{tabular}


Table 4 Number of regions in which families are represented

\begin{tabular}{|c|c|c|c|}
\hline Families & No. of regions & Families & No. of regions \\
\hline Hemiuridae Looss, 1899 & 13 & Haplosplanchnidae Poche, 1926 & 5 \\
\hline Opecoelidae Ozaki, 1925 & 13 & Ptychogonimidae Dollfus, 1937 & 5 \\
\hline Acanthocolpidae Lühe, 1906 & 12 & Aephnidiogenidae Yamaguti, 1934 & 4 \\
\hline Lecithasteridae Odhner, 1905 & 12 & Deropristidae Cable \& Hunninen, 1942 & 4 \\
\hline Lepocreadiidae Odhner, 1905 & 12 & Lissorchiidae Magath, 1917 & 4 \\
\hline Bucephalidae Poche, 1907 & 11 & Bathycotylidae Dollfus, 1932 & 3 \\
\hline Derogenidae Nicoll, 1910 & 11 & Gyliauchenidae Fukui, 1929 & 3 \\
\hline Fellodistomidae Nicoll, 1909 & 11 & Mesometridae Poche, 1926 & 3 \\
\hline Monorchiidae Odhner, 1911 & 11 & Dictysarcidae Skrjabin \& Guschanskaja, 1955 & 2 \\
\hline Zoogonidae Odhner, 1902 & 11 & Diplangidae Yamaguti, 1971 & 2 \\
\hline Cryptogonimidae Ward, 1917 & 10 & Enenteridae Yamaguti, 1958 & 2 \\
\hline Apocreadiidae Skrjabin, 1942 & 9 & Microscaphidiidae Looss, 1900 & 2 \\
\hline Didymozoidae Monticelli, 1888 & 9 & Pronocephalidae Looss, 1899 & 2 \\
\hline Hirudinellidae Dollfus, 1932 & 9 & Bivesiculidae Yamaguti, 1934 & 1 \\
\hline Sclerodistomidae Odhner, 1927 & 9 & Botulisaccidae Yamaguti, 1971 & 1 \\
\hline Accacoeliidae Looss, 1899 & 8 & Brachycladiidae Odhner, 1905 & 1 \\
\hline Aporocotylidae Odhner, 1912 & 8 & Cladorchiidae Fischoeder, 1901 & 1 \\
\hline Gorgoderidae Looss, 1899 & 8 & Echinostomatidae Looss, 1899 & 1 \\
\hline Haploporidae Nicoll, 1914 & 8 & Gorgocephalidae Manter, 1966 & 1 \\
\hline Lepidapedidae Yamaguti, 1958 & 8 & Microphallidae Ward, 1901 & 1 \\
\hline Syncoeliidae Looss, 1899 & 8 & Opistholebetidae Fukui, 1929 & 1 \\
\hline Azygiidae Lühe, 1909 & 7 & Opisthorchiidae Looss, 1899 & 1 \\
\hline Faustulidae Poche, 1926 & 7 & & \\
\hline
\end{tabular}

Bivesiculidae Yamaguti, 1934 are notable examples. Other families are seemingly missing from the Atlantic entirely, including the Transversotrematidae Witenberg, 1944 and the Atractotrematidae Yamaguti, 1939.

These data emphasize again the paucity of work in some regions. The Lepidapedidae Yamaguti, 1958 is mainly a deep-sea family and the lack of deep-sea studies in the southern part of the Atlantic in particular is highlighted by its occurrence in only eight zones. On the other hand, the paucity of records of microphallids, echinostomatids and brachycladiids probably reflects the real situation. Microphallids are rarely found in fishes, but they do occur there occasionally (Siddiqi \& Cable, 1960) and the occurrence of a brachycladiid in a shark is likely to be an accidental occurrence, although it was found in its usual site, the liver (Adams et al., 1998). The record of the ovigerous echinostomatid Himasthla tensa Linton, 1940 in the Atlantic cod Gadus morhua L. must also be considered an accidental infection (Linton, 1940).

\section{The Atlantic Ocean and the Eastern Pacific Ocean}

According to our database 109 species are shared between the Atlantic Ocean and the Eastern Pacific region. These can be divided into four categories.

Fifty three of the species are cosmopolitan species. Some are parasites of widespread pelagic hosts, e.g. Hirudinella ventricosa and many didymozoids and others are frequently reported seemingly highly nonhost-specific parasites, which may well represent cryptic complexes, e.g. Helicometrina nimia Linton, 1910, Helicometra fasciata (Rudolphi, 1819) Odhner, 1902 and Derogenes varicus. Recent studies (Calhoun et al., 2013) indicate that $H$. ventricosa is also a cryptic complex.

Thirteen species are circum-boreal, probably with a continuous population between the oceans via the Arctic Ocean (Table 5).

Only four species appear to have been reported in the southern parts of both oceans, in the Magellanic region which is continuous around Cape Horn. These 


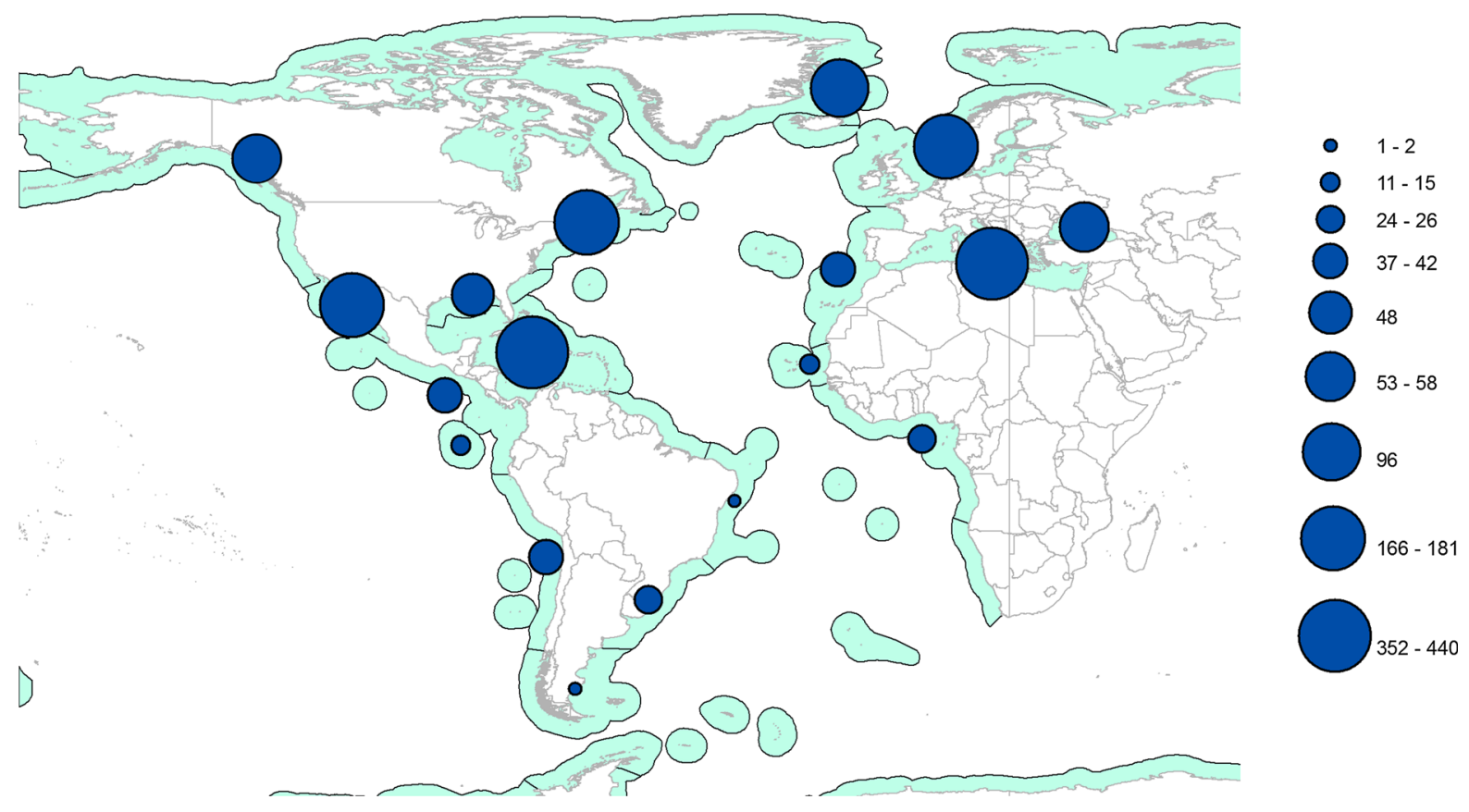

Fig. 2 Map of the Atlantic and Eastern Pacific Oceans, showing the number of records (indicated by the size of filled circles) of Opecoelidae in each 'Spalding et al.' Region

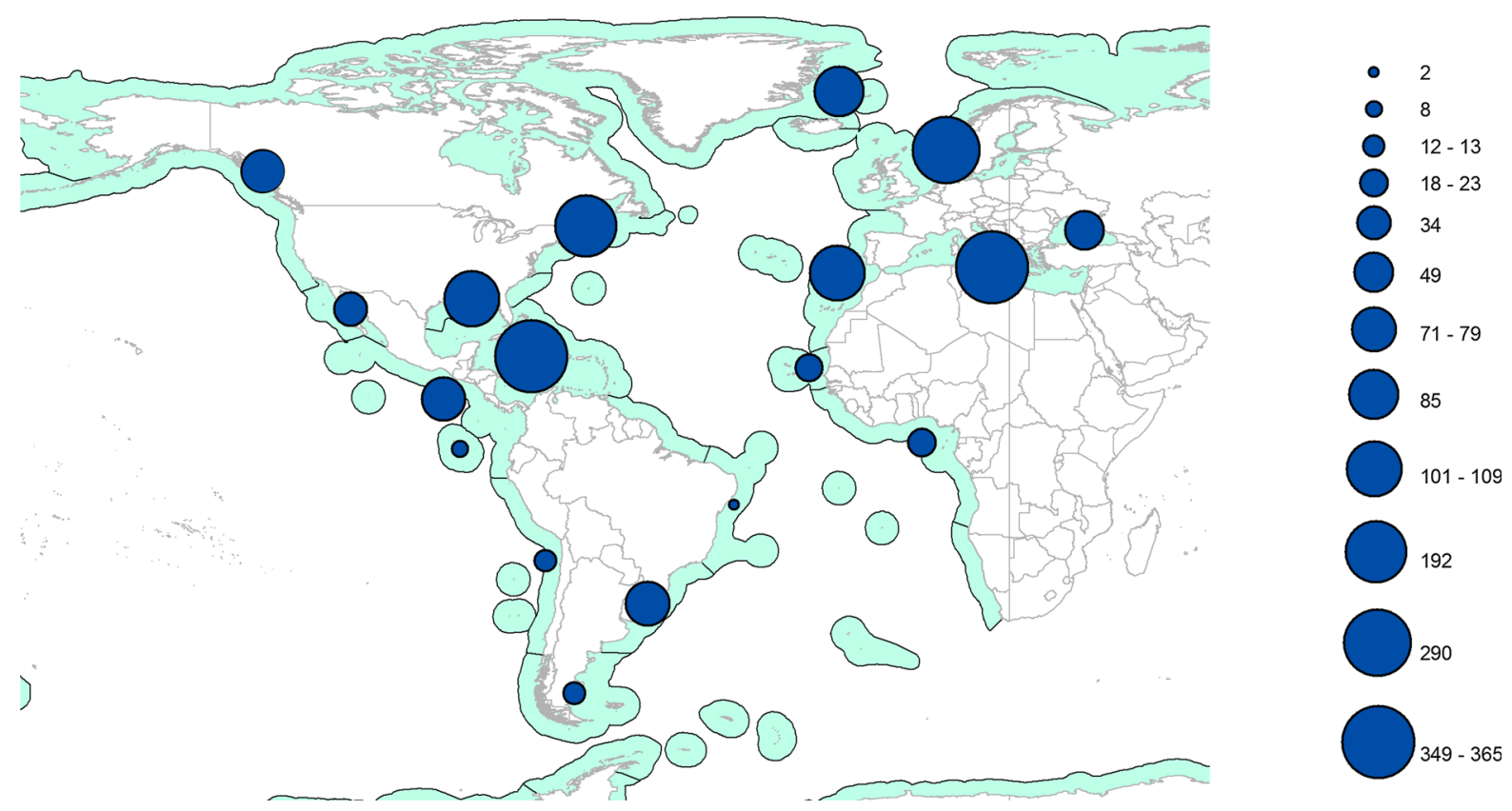

Fig. 3 Map of the Atlantic and Eastern Pacific Oceans, showing the number of records (indicated by the size of filled circles) of Hemiuridae in each 'Spalding et al.' Region

are Aporocotyle ymakara Villalba \& Fernández, 1986, Lecithochirium genypteri Manter, 1954, Neolebouria georgenascimentoi Bray, 2002 and Prosorhynchoides rioplatensis (Szidat, 1970) Lunaschi, 2003. Lecithochirium genypteri is, however, circum-austral having been originally reported in New Zealand 


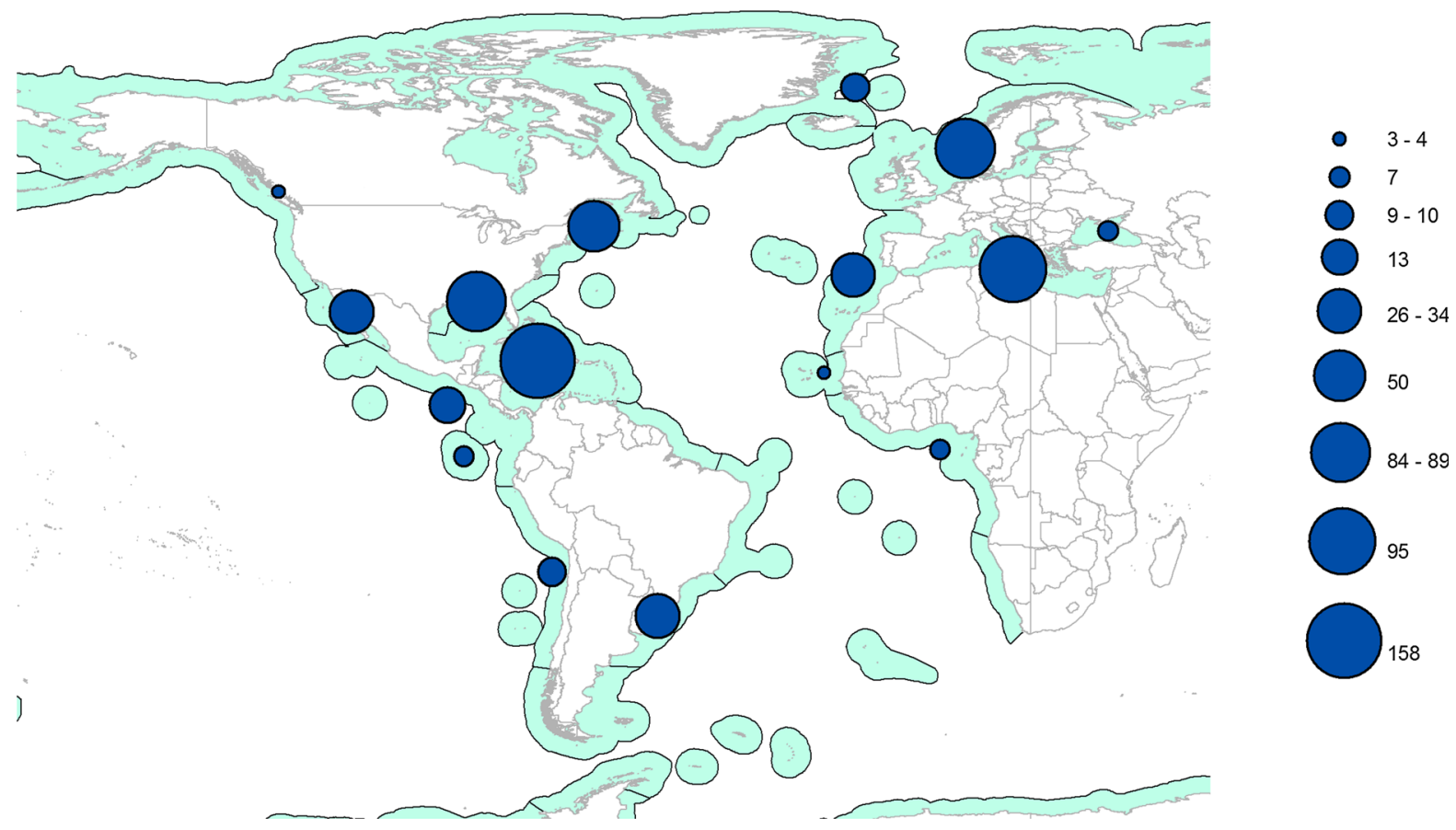

Fig. 4 Map of the Atlantic and Eastern Pacific Oceans, showing the number of records (indicated by the size of filled circles) of Bucephalidae in each 'Spalding et al.' Region

Table 5 Circum-boreal species, found in northern Atlantic and north-eastern Pacific regions

Aporocotyle simplex Odhner, 1900

Brachyphallus crenatus (Rudolphi, 1802)

Genolinea laticauda Manter, 1925

Hemiurus appendiculatus (Rudolphi, 1802)

Hemiurus levinseni Odhner, 1905

Lecithaster gibbosus (Rudolphi, 1802)

Lecithophyllum botryophoron (Olsson, 1868)

Podocotyle atomon (Rudolphi, 1802)

Steganoderma formosum Stafford, 1904

Stenakron vitellosum (Manter, 1934)

Stephanostomum baccatum (Nicoll, 1907)

Steringophorus furciger (Olsson, 1868)

Zoogonoides viviparus (Olsson, 1868)

(Manter 1954), and later in Australian and South African waters (Korotaeva, 1975; Bray, 1991).

The most interesting group of shared worms is that found on either side of the Isthmus of Panama. Our database includes 38 such species (Table 6). Molecular exploration of the distinctions between apparent conspecifics on either side of the isthmus would allow calibration of evolutionary rates if (and when) consensus is reached on the time of the closing of the isthmus (Bacon et al., 2015). A case in point is the species listed as Homalometron elongatum Manter, 1947, which has been reported mainly in the Caribbean region (Manter, 1947; Sogandares-Bernal, 1959; Siddiqi \& Cable, 1960; Fischthal, 1977; Bunkley-Williams et al., 1996; Parker et al., 2010), but also from two hosts and three localities in the Eastern Pacific (Sogandares-Bernal, 1959; Pérez-Ponce de León et al., 2007). Recent molecular work by Parker et al. (2010) has indicated that the Pacific form may well be a distinct, but genetically similar, species they named H. lesliorum Parker, Curran, Overstreet \& Tkach, 2010. They considered ' $H$. elongatum a widespread parasite of fishes throughout the Caribbean Sea, whereas H. lesliorum occurs in the Eastern Pacific Ocean off Central America'. There are some anomalies amongst the species in Table 6 in that as well as reports from the Eastern Pacific and western Atlantic, Haplosplanchnus mugilis Nahhas \& Cable, 1964 (see Parukhin et al., 1971; Al-Bassel, 1997) and Schikhobalotrema acuta (Linton, 1910) (see Fayek 
Table 6 Species found on either side of the Isthmus of Panama

Trans-Panama Isthmus species

Aponurus pyriformis (Linton, 1910)

Cainocreadium oscitans (Linton, 1910)

Cardicola cardiocola (Manter, 1947)

Cetiotrema carangis (Manter, 1947)

Deontacylix ovalis Linton, 1910

Dicrogaster fastigatus Thatcher \& Sparks, 1958

Haplosplanchnus mugilis Nahhas \& Cable, 1964

Haplosplanchnus sparisomae Manter, 1937

Homalometron elongatum Manter, 1947

Homalometron mexicanum (Manter, 1937)

Hymenocotta manteri Overstreet, 1969

Hypocreadium biminensis (Sogandares-Bernal, 1959)

Hypocreadium galapagoensis (Manter, 1945)

Hypocreadium scaphosomum (Manter, 1940)

Hysterolecitha brasiliensis de Oliveira, Amato \& Knoff, 1988

Lasiotocus longicaecum (Manter, 1940)

Lasiotocus truncatus (Linton, 1910)

Lecithochirium taboganus (Sogandares-Bernal, 1959)

Lecithophyllum intermedium (Manter, 1934)

\author{
Lepidapedoides nicolli (Manter, 1934) \\ Lepocreadium bimarinum Manter, 1940 \\ Metadena globosa (Linton, 1910) \\ Myodera magna Sogandares-Bernal, 1959 \\ Neolepidapedoides trachinoti (Siddiqi \& Cable, 1960) \\ Opecoeloides fimbriatus (Linton, 1934) \\ Pachycreadium gastrocotylum (Manter, 1940) \\ Prosorhynchoides labiatus (Manter \& Van Cleave, 1951) \\ Prosorhynchus gonoderus Manter, 1940 \\ Prosorhynchus ozakii Manter, 1934 \\ Pseudoacanthostomum panamensis \\ Caballero, Bravo-Hollis \& Grocott, 1953 \\ Pseudolepidapedon balistis Manter, 1940 \\ Pseudopecoelus priacanthi (MacCallum, 1921) \\ Schikhobalotrema acuta (Linton, 1910) \\ Schikhobalotrema pomacentri (Manter, 1937) \\ Siphodera vinaledwardsii (Linton, 1901) \\ Stephanostomum megacephalum Manter, 1940 \\ Stephanostomum provitellosum Sogandares-Bernal, 1959 \\ Stephanostomum tenue (Linton, 1898)
}

et al., 1990) have both been reported from the Mediterranean Sea. It is likely that these are misidentifications.

The remaining species reported in both the Atlantic Ocean and the Eastern Pacific Ocean is Tubulovesicula lindbergi (Layman, 1930) Yamaguti, 1934, originally reported from Peter the Great Bay off Northeastern Russia (Layman, 1930), and well reported in both the western and the eastern North Pacific. The two reports from the Atlantic, from off Puerto Rico (Siddiqi \& Cable, 1960) and Ghana (Fischthal \& Thomas, 1972), are puzzling and probably represent misidentifications. This situation also illustrates the problems encountered in studies based on large databases, where it is not possible to verify every record.

\section{Lessepsian migration}

The effect of man on the distribution of marine digeneans is exemplified by the effects of migration through the Suez Canal, so-called Lessepsian migration. We can be confident that this is changing the fauna, but to what extent it is not yet clear. For example, the herbivorous rabbit fish Siganus rivulatus Forsskål \& Niebuhr has passed into the Mediterranean Sea, causing great damage to native algal assemblages (Sala et al., 2011), and bringing with it the wide-spread Indo-Pacific parasite Thulinia microrchis (Yamaguti, 1934) Bray, Cribb \& Barker, 1993 (as Hysterolecitha sigani Manter, 1969) (see Fischthal, 1980; Bray et al., 1993). Also, recently, the cornetfish Fistularia commersonii Rüppell has spread right across the Mediterranean Sea along with its parasite Allolepidapedon fistulariae Yamaguti, 1940 (and other worms) (Pais et al., 2007). It is not yet known if these Lessepsian migrant parasites have spread into the open Atlantic Ocean. With the opening in August 2015 of a new channel parallel to the old one, the exchange of fauna between the Red and Mediterranean Seas is bound to increase (Galil et al., 2015).

\section{Concluding remark}

Our data suggest 1,125 species in 384 genera and 45 families are reported in marine fishes of the Atlantic 
Ocean basin; almost 1,000 of these species are endemic to the Atlantic Ocean. The geographical region which is most poorly known is the South Eastern Atlantic Ocean, with few reports and, apparently, no current research. The deep-sea of the southern part of the Atlantic Ocean is also virtually un-studied.

The discovery of cryptic species in the Atlantic is in its early stages and will, without doubt, alter our understanding of the Atlantic digenean fauna as it has already in parts of the Indo-West Pacific (Miller et al., 2011). A molecular study of trans-Panama Isthmus species has the promise of estimation of speciation times and rates. There is much to be done, but modern techniques hold out much promise and could lead to an exciting future for workers in this Ocean.

\section{Compliance with ethical standards}

Conflict of interest The authors declare that they have no conflict of interest.

Ethical approval This article does not contain any studies with animals performed by any of the authors.

Open Access This article is distributed under the terms of the Creative Commons Attribution 4.0 International License (http:// creativecommons.org/licenses/by/4.0/), which permits unrestricted use, distribution, and reproduction in any medium, provided you give appropriate credit to the original author(s) and the source, provide a link to the Creative Commons license, and indicate if changes were made.

\section{References}

Adams, A. M., Hoberg, E. P., McAlpine, D. F., \& Clayden, S. L. (1998). Occurrence and morphological comparisons of Campula oblonga (Digenea: Campulidae), including a report from an atypical host, the thresher shark, Alopias vulpinus. Journal of Parasitology, 84, 435-438.

Al-Bassel, D. A. M. L. (1997). A review of the trematode genera Haplosplanchnus Looss, 1902 and Prohaplosplanchnus Tang and Lin, 1978 with redescription of three species from the mullet in Libya. Qatar University Science Journal, 17, 133-142.

Andres, M. J., Ray, C. L., Pulis, E. E., Curran, S. S., \& Overstreet, R. M. (2014). Molecular characterization of two opecoelid trematodes from fishes in the Gulf of Mexico, with a description of a new species of Helicometra. Acta Parasitologica, 59, 405-412.

Antar, R., Georgieva, S., Gargouri, L., \& Kostadinova, A. (2015). Molecular evidence for the existence of species complexes within Macvicaria Gibson \& Bray, 1982 (Digenea: Opecoelidae) in the western Mediterranean, with descriptions of two new species. Systematic Parasitology, 91, 211-229.

Bacon, C. D., Silvestro, D., Jaramillo, C., Smith, B. T., Chakrabarty, P., \& Antonelli, A. (2015). Biological evidence supports an early and complex emergence of the Isthmus of Panama. Proceedings of the National Academy of Sciences of the United States of America, 112, 6110-6115.

Blasco-Costa, I., Balbuena, J. A., Kostadinova, A., \& Olson, P. D. (2009a). Interrelationships of the Haploporinae (Digenea: Haploporidae): A molecular test of the taxonomic framework based on morphology. Parasitology International, 58, 263-269.

Blasco-Costa, I., Balbuena, J. A., Raga, J. A., Kostadinova, A., \& Olson, P. D. (2010). Molecules and morphology reveal cryptic variation among digeneans infecting sympatric mullets in the Mediterranean. Parasitology, 137, 287-302.

Blasco-Costa, I., Montero, F. E., Balbuena, J. A., Raga, J. A., \& Kostadinova, A. (2009b). A revision of the Haploporinae Nicoll, 1914 (Digenea: Haploporidae) from mullets (Mugilidae): Dicrogaster Looss, 1902 and Forticulcita Overstreet, 1982. Systematic Parasitology, 72, 187-206.

Bray, R. A. (1991). Hemiuridae (Digenea) from marine fishes of the southern Indian Ocean: Genus Lecithochirium Lühe, 1901 (Lecithochiriinae). Systematic Parasitology, 18, 193-219.

Bray, R. A., Cribb, T. H., \& Barker, S. C. (1993). The Hemiuroidea (Digenea) of pomacentrid fishes (Perciformes) from Heron Island, Queensland, Australia. Systematic Parasitology, 24, 159-184.

Bray, R. A., Gibson, D. I., \& Jones, A. (Eds) (2008). Keys to the Trematoda. Volume 3. Wallingford, UK: CABI Publishing and the Natural History Museum.

Bray, R. A., Littlewood, D. T. J., Herniou, E. A., Williams, B., \& Henderson, R. E. (1999). Digenean parasites of deep-sea teleosts: A review and case studies of intrageneric phylogenies. Parasitology, 119(Supplement), S125-S144.

Bray, R. A., Soto, A., \& Rollinson, D. (1994). The status and composition of the genus Steringophorus Odhner, 1905 (Digenea: Fellodistomidae), based on partial small subunit rRNA sequences. International Journal for Parasitology, 24, 433-435.

Bunkley-Williams, L., Dyer, W. G., \& Williams, E. H, Jr. (1996). Some aspidogastrid and digenean trematodes of Puerto Rican marine fishes. Journal of Aquatic Animal Health, 8, 87-92.

Calhoun, D. M., Curran, S. S., Pulis, E. E., Provaznik, J. M., \& Franks, J. S. (2013). Hirudinella ventricosa (Pallas, 1774) Baird, 1853 represents a species complex based on ribosomal DNA. Systematic Parasitology, 86, 197-208.

Cobbold, T. S. (1858). Observations on Entozoa, with notices of several new species, including an account of two experiments in regard to the breeding of Taenia serrata and $T$. cucumerina. Transactions of the Linnean Society, London, 22, 155-172.

Curran, S. S., \& Pulis, E. E. (2014). Confirmation of Pseudolepidapedon balistis in the Acanthocolpidae (Digenea) based on phylogenetic analysis of ribosomal DNA. Journal of Parasitology, 100, 856-859.

Dujardin, F. (1845). Histoire naturelle des helminthes ou vers intestinaux. Paris: Librairie Encyclopédique de Roret, 654 pp. 
Fayek, S. A., Amer, O. H., \& Ahmed, N. E. (1990). Some fish trematodes from the Mediterranean Sea. Veterinary Medical Journal (Giza), 38, 429-438.

Fischthal, J. H. (1977). Some digenetic trematodes of marine fishes from the Barrier Reef and Reef Lagoon of Belize. Zoologica Scripta, 6, 81-88.

Fischthal, J. H. (1980). Some digenetic trematodes of marine fishes from Israel's Mediterranean coast and their zoogeography, especially those from Red Sea immigrant fishes. Zoologica Scripta, 9, 11-23.

Fischthal, J. H., \& Thomas, J. D. (1972). Additional hemiurid and other trematodes of fishes from Ghana. Bulletin de l'Institut Fondametal d'Afrique Noire, Series A, Science Naturelles, 34, 9-25.

Galil, B. S., Boero, F., Campbell, M. L., Carlton, J. T., Cook, E., Fraschetti, S., et al. (2015). 'Double trouble': The expansion of the Suez Canal and marine bioinvasions in the Mediterranean Sea. Biological Invasions, 17, 973-976.

Gibson, D. I. (1976). Monogenea and Digenea from fishes. Discovery Reports, 36, 182-266.

Gibson, D. I., Jones, A., \& Bray, R. A. (Eds) (2002). Keys to the Trematoda. Volume 1. Wallingford, UK: CABI Publishing and the Natural History Museum.

Jones, A., Bray, R. A., \& Gibson, D. I. (Eds) (2005). Keys to the Trematoda. Volume 2. Wallingford, UK: CABI Publishing and the Natural History Museum.

Jousson, O. (2001). Les trématodes digénétiques parasites de poissons en Méditerranée occidentale: cycles biologiques, diversité cryptique et évolution moléculaire. $\mathrm{PhD}$ Thesis, Université de Genève, Geneva.

Jousson, O., Bartoli, P., \& Pawlowski, J. (1999). Molecular identification of developmental stages in Opecoelidae (Digenea). International Journal for Parasitology, 29, 1853-1858.

Jousson, O., Bartoli, P., \& Pawlowski, J. (2000). Cryptic speciation among intestinal parasites (Trematoda: Digenea) infecting sympatric host fishes (Sparidae). Journal of Evolutionary Biology, 13, 778-785.

Køie, M. (1975). On the morphology and life-history of Opechona bacillaris (Molin, 1859) Looss, 1907 (Trematoda, Lepocreadiidae). Ophelia, 13, 63-86.

Køie, M. (1995). The life-cycle and biology of Hemiurus communis Odhner, 1905 (Digenea, Hemiuridae). Parasite, 2, 195-202.

Korotaeva, V. D. (1975). Contribution to the fauna of helminths and parasitic crustaceans of marine commercial fishes of the Australian and New Zealand waters. Trudy Biologo-pochvennogo Instituta Novaya Seriya, 26, 46-60 (In Russian).

Layman, E. M. (1930). Parasitic worms from the fishes of Peter The Great Bay. Izvestiya Tikhookeanskoi Nauchno-Promyslovi Stantsii, 3, 1-120 (In Russian and German).

Leidy, J. (1891). Notices of Entozoa. Proceedings of the Academy of Natural Sciences of Philadelphia, 1890, 410-418.

Linton, E. (1889). Notes on Entozoa of marine fishes of New England, with descriptions of several new species. Annual Report of the Commissioner of Fish and Fisheries (1886), 14, 453-511.

Linton, E. (1910). Helminth fauna of the Dry Tortugas. II. Trematodes. Papers from the Tortugas Laboratory of the Carnegie Institute of Washington, 4, 11-98.
Linton, E. (1940). Trematodes from fishes mainly from the Woods Hole region, Massachusetts. Proceedings of the United States National Museum, 88, 1-172.

Lumb, S. M., Bray, R. A., \& Rollinson, D. (1993). Partial small subunit (18S) rRNA gene sequences from fish parasites of the families Lepocreadiidae and Fellodistomidae (Digenea) and their use in phylogenetic analyses. Systematic Parasitology, 26, 141-149.

Manter, H. W. (1925). Some marine fish trematodes of Maine. Journal of Parasitology, 12, 11-18.

Manter, H. W. (1947). The digenetic trematodes of marine fishes of Tortugas, Florida. American Midland Naturalist, 38, 257-416.

Manter, H. W. (1954). Some digenetic trematodes from fishes of New Zealand. Transactions of the Royal Society of New Zealand, 82, 475-568.

Miller, M. J. (1941). A critical study of Stafford's report on "Trematodes of Canadian fishes" based on his trematode collection. Canadian Journal of Research, 19, 28-52.

Miller, T. L., Bray, R. A., \& Cribb, T. H. (2011). Taxonomic approaches to and interpretation of host specificity of trematodes of fishes: lessons from the Great Barrier Reef. Parasitology, 138, 1710-1722.

Müller, O. F. (1784). Zoologia Danica seu animalium Daniae et Norvegiae rariorum ac minus notorum descriptiones et historia. Volumen secundum. Havniae et Lipsiae: Sumtibus Weygandinis, $124 \mathrm{pp}$.

Nolan, M. J., Curran, S. S., Miller, T. L., Cutmore, S. C., Cantacessi, C., \& Cribb, T. H. (2015). Dollfustrema durum n. sp. and Heterobucephalopsis perardua n. sp. (Digenea: Bucephalidae) from the giant moray eel, Gymnothorax javanicus (Bleeker) (Anguilliformes: Muraenidae), and proposal of the Heterobucephalopsinae n. subfam. Parasitology International, 64, 559-570.

Odhner, T. (1905). Die Trematoden des arktischen Gebietes. Fauna Arctica, 4, 289-374.

Olsson, P. (1868). Entozoa, iakttagna hos Skandinaviska hafsfiskar. I. Platyhelminthes. Acta Universitatis Lundensis, 4, $1-64$.

Pais, A., Merella, P., Follesa, M. C., \& Garippa, G. (2007). Westward range expansion of the Lessepsian migrant Fistularia commersonii (Fistulariidae) in the Mediterranean Sea, with notes on its parasites. Journal of Fish Biology, 70, 269-277.

Pallas, P. S. (1774). Spicilegia zoologica quibas novae imprimus et obscurae animalium species inconibus, descriptionibus atque commentariis illustrantur. Fasc. 10. Berolini, p. 41.

Parker, J. H., Curran, S. S., Overstreet, R. M., \& Tkach, V. V. (2010). Examination of Homalometron elongatum Manter, 1947 and description of a new congener from Eucinostomus currani Zahuranec, 1980 in the Pacific Ocean off Costa Rica. Comparative Parasitology, 77, 154-163.

Parukhin, A. M., Naidenova, N. N., \& Nikolaeva, V. M. (1971). The parasite fauna of fishes caught in the Mediterranean Sea. In Vodjanichky, V. A. (Ed.) Expeditionary investigations in the Mediterranean Sea in May-July 1970 (66th voyage of the $R V A k$. A. Kovalevsky). Kiev: Naukova Dumka, pp. 64-87 (In Russian).

Pérez-del-Olmo, A., Kostadinova, A., \& Gibson, D. I. (2016). The Mediterranean: High discovery rates for a well-studied trematode fauna. Systematic Parasitology (in press). 
Pérez-Ponce de León, G., Garcia-Prieto, L., \& Mendoza-Garfias, B. (2007). Trematode parasites (Platyhelminthes) of wildlife vertebrates in Mexico. Zootaxa, 1534, 1-247.

Pulis, E. E., Curran, S. S., Andres, M. J., \& Overstreet, R. M. (2014). Change in rank of Megaperidae (Trematoda) to Megaperinae within the Apocreadiidae and description of Haintestinum amplum n. g., n. sp. Parasitology International, 63, 269-274.

Sala, E., Kizilkaya, Z., Yildirim, D., \& Ballesteros, E. (2011). Alien marine fishes deplete algal biomass in the eastern Mediterranean. Plos One, 6, e17356.

Siddiqi, A. H., \& Cable, R. M. (1960). Digenetic trematodes of marine fishes of Puerto Rico. Scientific Survey of Porto Rico and the Virgin Islands, 17, 257-369.

Sogandares-Bernal, F. (1959). Digenetic trematodes of marine fishes from the Gulf of Panama and Bimini, British West Indies. Tulane Studies in Zoology, 7, 69-117.

Spalding, M. D., Fox, H. E., Halpern, B. S., McManus, M. A., Molnar, J., Allen, G. R., et al. (2007). Marine ecoregions of the world: A bioregionalization of coastal and shelf areas. Bioscience, 57, 573-583.
Stafford, J. (1904). Trematodes from Canadian fishes. Zoologischer Anzeiger, 27, 481-495.

Stunkard, H. W., \& Uzmann, J. R. (1959). The life-cycle of the digenetic trematode, Proctoeces maculatus (Looss, 1901) Odhner, 1911 [syn. P. subtenuis (Linton, 1907) Hanson, 1950], and description of Cercaria adranocerca n. sp. Biological Bulletin. Marine Biological Laboratory, 116, 184-193.

Szidat, L. (1950). Los parásitos del róbalo (Eleginops maclovinus Cuv. and Val.). Primer Congreso Nacional de Pesquerías Marítimas e Industria Derivadas, Mar del Plata, 24-29th October 1949. Buenos Aires, 2, 235-270.

Thomas, J. D. (1959). Trematodes of Ghanaian sub-littoral fishes. I. The family Monorchiidae. Journal of Parasitology, 45, 95-113.

van Beneden, P.-J. (1871). Les poissons des côtes de Belgiques, leurs parasites et leurs commensaux. Mémoires de l'Académie Royal des Sciences, des Lettres et des Beaux-Arts de Belgique, 38, $\mathrm{i}-\mathrm{xx}+1-100$.

WoRMS Editorial Board (2015). World Register of Marine Species. Available from http://www.marinespecies.org at VLIZ. 